\title{
Dampak Wisata Bahari bagi Kondisi Ekonomi Masyarakat Desa Kolorai, Kecamatan Morotai Selatan, Kabupaten Pulau Morotai
}

\author{
M. Adhiyaksa ${ }^{a}$, Annisa Mu'awanah Sukmawati ${ }^{a}$ \\ a Program Studi Perencanaan Wilayah dan Kota, Fakultas Sains dan Teknologi, Universitas Teknologi Yogyakarta, Indonesia \\ E-mail Correspondence: aldiadhiyaksa98@gmail.com
}

\begin{abstract}
Abstrak: Desa Kolorai memiliki potensi wisata yang beragam, baik wisata budaya, wisata alam, dan wisata bahari. Wisata bahari merupakan jenis wisata yang menjadi unggulan bagi Desa Kolorai dan berpeluang memberikan dampak positif bagi pengembangan ekonomi masyarakat di pesisir pantai. Penelitian berlokasi di Desa Kolorai, Kecamatan Morotai Selatan, Kabupaten Pulau Morotai. Penelitian bertujuan untuk menganalisis dampak pariwisata bahari terhadap kondisi ekonomi masyarakat lokal di Desa Kolorai, Kecamatan Morotai Selatan, Kabupaten Pulau Morotai. Metode penelitian yang digunakan adalah metode kuantitatif dengan teknik analisis Crosstab untuk melihat korelasi antara keberadaan wisata bahari dengan perubahan tingkat pendapatan. Pengumpulan data dilakukan dengan teknik pengumpulan data primer melalui kuesioner, wawancara, dan observasi lapangan serta pengumpulan data sekunder dari telaah dokumen. Hasil penelitian menunjukkan bahwa keberadaan wisata bahari di Desa Kolorai memberi dampak yang cukup signifikan bagi perekonomian masyarakat lokal. Hal ini terlihat dari adanya peluang mata pencaharian baru bagi masyarakat lokal yang tidak hanya sebagai nelayan, namun juga sebagai pelaku usaha wisata terkait kelautan dan penyedia jasa akomodasi wisata. Keberadaan aksesibilitas dan diversifikasi daya tarik wisata juga berpengaruh bagi dinamika pendapatan masyarakat di sektor wisata bahari.
\end{abstract}

Kata Kunci: dampak ekonomi, Desa Kolorai, wisata bahari

\begin{abstract}
Kolorai Village has a variety of tourism potentials, they are cultural tourism, nature tourism, and marine tourism. Marine tourism is a type of tourism that has become the mainstay of Kolorai Village and has the opportunity to have a positive impact on the economic development of coastal communities. The research is located in Kolorai Village, South Morotai District, Morotai Island Regency. This study aims to analyze the impact of marine tourism on the economic conditions of the local people in Kolorai Village, South Morotai District, Morotai Island Regency. The research method conducted by using a quantitative method with Crosstab analysis techniques to exam the correlation between the existence of marine tourism and changes in income levels. Data collection was carried out by collecting primary data through questionnaires, interviews, and field observations as well as secondary data collection from document review. The results showed that the presence of marine tourism in Kolorai Village had a significant impact on the economy of the local community. This can be seen from the existence of new livelihood opportunities for local people who are not only as fishermen but also as marine tourism business actors and tourism accommodation service providers. The existence of accessibility and diversification of tourist attractions also affects the dynamics of community income in the marine tourism sector.
\end{abstract}

Keywords: economic impact, Kolorai Village, marine tourism

How to cite (APA 6th Style):

Adhiyaksa, M. \& Sukmawati, A. M. (2021). Dampak Wisata Bahari bagi Kondisi Ekonomi Masyarakat Desa Kolorai, Kecamatan Morotai Selatan, Kabupaten Pulau Morotai, 2 (2), 7-18. doi: 10.26418/uniplan.v2i2.46501

\section{PENDAHULUAN}

Sektor pariwisata adalah sektor yang memiliki peran penting bagi perkembangan ekonomi suatu wilayah. Ini dikarenakan dampak multiplier effect dari sektor pariwisata bagi perkembangan sektor lainnya dan berkontribusi bagi pendapatan suatu daerah. Selain itu, sektor pariwisata juga berpotensi menjadi generator penggerak ekonomi suatu wilayah karena berpeluang memberikan dan memperluas lapangan kerja, mendorong keterlibatan masyarakat di dalamnya, dan menjadi media pemasaran suatu wilayah (Razak et al., 2017). 
Wisata bahari adalah salah satu jenis daya tarik wisata yan 'g potensial dikembangkan bagi wilayah yang memiliki potensi kekayaan alam berupa laut atau pantai. Menurut Muljadi \& Warman (2014), wisata bahari adalah aktivitas perjalanan yang berhubungan dengan laut atau keairan. Aktivitas wisata bahari dapat berupa menikmati keindahan alam maupun melakukan aktivitas olahraga terkait air. Selain berkontribusi bagi aspek ekonomi, wisata bahari juga hendaknya berprinsip pada kelestarian alam, seperti tidak merusak dan mencemari ekosistem laut (Muljadi \& Warman, 2014). Lebih lanjut, hasil penelitian Nastiti \& Umilia (2013) menunjukkan mengenai beberapa faktor yang dapat mempengaruhi perkembangan wisata bahari, meliputi daya tarik wisata, ketersediaan sarana dan prasarana penunjang aktivitas wisata, partisipasi masyarakat setempat, keberadaan dan peran kelembagaan pariwisata, kesempatan investasi, kualitas lingkungan, perlindungan sumberdaya, kebijakan pemerintah, dan pemasaran.

Keberadaan wisata bahari dapat menjadi alternatif bagi suatu daerah untuk menambah sumber pendapatan daerah. Beberapa penelitian menunjukkan mengenai peran wisata bagi bagi peningkatan ekonomi dan kesejahteraan masyarakat, meliputi tingkat pendapatan masyarakat, kesempatan bekerja, harga-harga, dan jasa akomodiasi wisata di suatu wilayah (Hiariey \& Sahusialawane, 2013; Rahman \& Muktialie, 2014; Shantika \& Mahagangga, 2018). Begitu pula wisata bahari yang memiliki dampak bagi pendapatan masyarakat. Penelitian Muawanah et al. (2020) mengenai dampak wisata bahari di Pulau Alor menunjukkan bahwa ekowisata di Pulau Alor dapat memberikan multiplier income bagi pendapatan masyarakat lokal. Hal ini tidak terlepas dari peran stakeholder pendukung seperti agen perjalanan dan LSM yang berperan dalam pemasaran ekowisata. Serupa dengan temuan Fyka et al. (2018) mengenai dampak wisata bahari di Pulau Bokori bahwa keberadaan wisata mampu memberi variasi bagi mata pencaharian penduduk, seperti munculnya usaha jasa penyeberangan, pedagang kaki lima, penyewaan alat-alat, dan penjual makanan. Dari aspek sosial, keberadaan wisata bahari juga mempengaruhi perilaku sosial masyarakat, seperti gaya hidup dan cara berkomunikasi. Begitu pula dengan temuan Dritasto \& Anggraeni (2013) bahwa aktivitas wisata bahari mampu memberikan dampak luas bagi peningkatan perekonomian masyarakat karena mendorong terjadinya perputaran uang, munculnya usaha-usaha baru, dan menyerap tenaga kerja.

Provinsi Maluku Utara memiliki potensi wisata beragam, seperti wisata alam, wisata budaya dan wisata sejarah berupa peninggalan benda-benda kebudayaan masa lalu, serta wisata bahari yang bersumber dari keindahan lautnya. Dalam kepariwisataan di Maluku Utara terdapat beberapa pulau yang memiliki objekobjek wisata menarik yang memiliki potensi ekowisata sejarah dan berpengaruh salah satunya adalah Kabupaten Pulau Morotai.

Kabupaten Pulau Morotai merupakan sebuah pulau sekaligus kabupaten yang terletak di Pulau Halmahera, sebagai bagian dari Provinsi Maluku Utara. Pulau Morotai memiliki luas wilayah 2.314,90 km², meliputi pulau-pulau (daratan) dan lautan dengan 5 Kecamatan. Pusat pemerintahan dan ibukota Kabupaten Pulau Morotai adalah Kecamatan Morotai Selatan. Sarana transportasi dari Pulau Halmahera ke Pulau Morotai ini dapat menggunakan kapal penumpang (ferry) dan speed boat. Pulau Morotai sebagai salah satu wilayah pulau terluar bagian utara menghadap kepada Samudera Pasifik memiliki keunggulan ekonomi serta memiliki potensi sumber daya bahari yang kaya dan juga memiliki daya tarik wisata budaya sejarah, yaitu peninggalan Perang Dunia II.

Penelitian berlokasi di Desa Kolorai, Kecamatan Morotai Selatan. Desa Kolorai memiliki potensi wisata bahari karena berbatasan langsung dengan laut. Desa Kolorai memiliki luas wilayah 4,33 $\mathrm{km}^{2}$. Jika dilihat berdasarkan penggunaan lahannya, seluas $2,00 \mathrm{~km}^{2}$ merupakan lahan non pertanian. Batas wilayah Desa Kolorai meliputi sebelah utara berbatasan dengan Kecamatan Morotai Timur, sebelah barat berbatasan dengan Selat Morotai, sebelah timur berbatasan dengan Kecamatan Morotai Selatan bagian barat, dan sebelah selatan berbatasan dengan Selat Morotai. Peta administrasi Desa Kolorai terlihat di Gambar 1. 


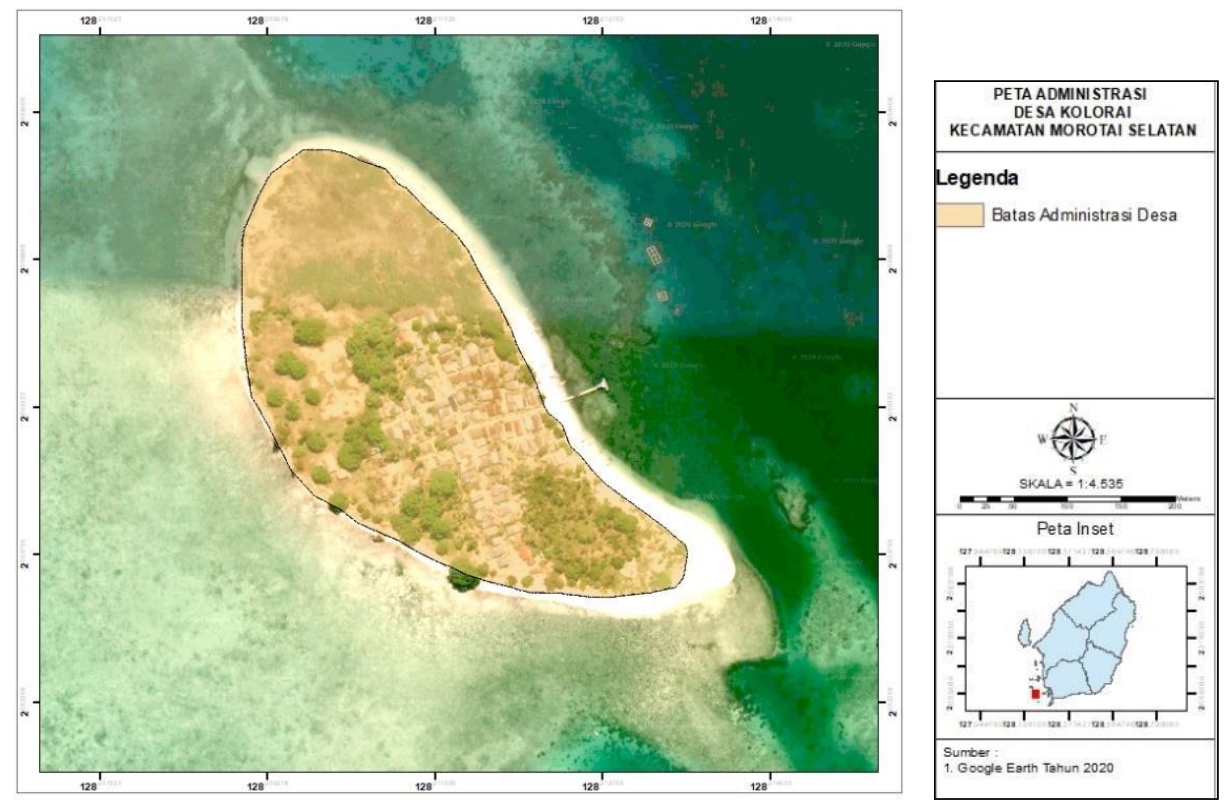

Gambar 1. Peta Administrasi Desa Kolorai (Penulis, 2020)

Desa Kolorai memiliki potensi wisata bahari yang unik dengan keindahan alam bawah laut. Ini dikarenakan wisata bahari di Desa Kolorai berlokasi pada tempat yang memiliki lingkungan alami, sejuk, dan sehat sehingga dapat mencapai suatu kegiatan rekreasi yang optimal. Desa Kolorai memiliki potensi wisata bahari berupa pulau-pulau kecil dan pantai-pantai yang indah. Pantai-pantai di Desa Kolorai, selain memiliki pasir yang putih juga memiliki air laut yang jernih serta pemandangan yang indah. Dari beberapa daya tarik wisata pantai tersebut, yang cukup menjadi daya tarik pengunjung adalah pantai di Pulau Dodola Besar dan Dodolan Kecil. Ini dikarenakan pulau tersebut memiliki keindahan laut serta wisatawan dapat menikmati olahraga laut, seperti diving dan snorkeling.

Keberadaan wisata bahari di Desa Kolorai berpotensi untuk meningkatkan Pendapatan Asli Daerah secara makro, perekonomian masyarakat lokal khususnya para pelaku usaha wisata, dan nilai-nilai budaya serta kehidupan sosial masyarakat lokal. Kunjungan wisatawan ke objek wisata Desa Kolorai dapat mempengaruhi budaya dan nilai-nilai sosial masyarakat setempat yang berada dalam lingkungan objek pariwisata karena akulturasi budaya yang berbeda dengan masyarakat setempat sehingga akan berpengaruh terhadap perkembangan objek wisata selanjutnya. Pengembangan wisata bahari di Desa Kolorai dapat memberikan dampak positif bagi masyarakat pesisir pantai. Meskipun peluang ekonomi cukup baik, namun pengembangan wisata bahari ini belum melibatkan masyarakat pesisir pantai Desa Kolorai seluruhnya. Selain itu, untuk kedepannya dengan adanya peningkatan jumlah kunjungan juga berpeluang menimbulkan dampak negatif bagi kelestarian lingkungan jika pengelolaan wisata alam tidak dikelola dengan baik, khususnya bagi masyarakat lokal yang bertempat tinggal di sekitar kawasan wisata bahari di Desa Kolorai. Ini karena dalam Undang-Undang No.10 Tahun 2009 tentang Kepariwisataan, Kabupaten Pulau Morotai memiliki modal untuk dikembangkan sebagai destinasi wisata andalan di Provinsi Maluku Utara. Untuk itu, perlu dirumuskan konsep pengembangan pariwisata yang tepat dan berkelanjutan yang tercantum dalam Rencana Induk Pembangunan Kepariwisataan Daerah (Ripparda) agar kelangsungan industri pariwisata di Pulau Morotai dapat berdampak maksimal, tidak hanya berorientasi pada ekonomi, tetapi juga memperhatikan dari sisi keberlanjutannya baik aspek kepariwisataannya maupun dari sisi lingkungan. Hasil penelitian Koroy et al., (2018) juga menunjukkan bahwa Pulau Dodola adalah salah sati destinasi wisata bahari di Pulau Kolorai yang memiliki kekayaan sumber daya alam ekosistem terumbu karang sehingga perlu diperhatikan kapasitas daya dukung lingkungan untuk mencegah kerusakan terumbu karang yang dapat berdampak pada lingkungan dan ekosistem lainnya. Sebagai salah satu Kawasan yang dicanangkan menjadi destinasi wisata unggulan dan diprioritaskan karena masuk ke dalam Kawasan Strategis Pariwisata Nasional (KSPN), Pulau Morotai perlu 
dipersiapkan dan dikelola dengan baik, seperti aspek 4A (atraksi, amenitas, aksesibilitas, dan ancillary) dan partisipasi/ keterlibatan masyarakat lokal (Astuti \& Noor, 2016; Natan, 2016).

Berdasarkan latar belakang tersebut, penelitian ini bertujuan untuk menganalisis dampak wisata bahari bagi kondisi ekonomi masyarakat di Desa Kolorai, Kecamatan Morotai Selatan, Kabupaten Pulau Morotai. Adapun fokus analisis adalah pada perubahan tingkat pendapatan sebelum dan sesudah bermatapencaharian pada sektor wisata bahari. Penelitian ini memiliki urgensi untuk mengetahui dampak yang ditimbulkan dari aktivitas pariwisata bahari yang berkaitan dengan ekonomi masyarakat lokal guna mendukung keberhasilan dan keberlanjutan pengembangan pariwisata bahari di Desa Kolorai.

\section{DATA DAN METODE}

Penelitian menggunakan metode penelitian kuantitatif. Ini dikarenakan penelitian bertujuan untuk menganalisis dampak wisata bahari bagi kondisi ekonomi masyarakat di Desa Kolorai, Kecamatan Morotai Selatan, Kabupaten Pulau Morotai. Pengumpulan data dilakukan dengan metode pengumpulan data primer meliputi kuesioner, wawancara, dan observasi lapangan. Kuesioner dilakukan dengan menggunakan teknik simple random sampling kepada 53 responden, yaitu penduduk Desa Kolorai yang bekerja di sektor wisata bahari. Wawancara dilakukan kepada Kepala Desa Kolorai dan Dinas Pariwisata Kabupaten Pulau Morotai untuk menggali informasi mengenai keberadaan wisata bahari dan dampaknya bagi masyarakat sekitar. Observasi lapangan ditujukan untuk mengamati mengenai kehidupan masyarakat Desa Kolorai, khususnya di sektor wisata bahari. Sedangkan metode pengumpulan data sekunder berupaya untuk menemukan informasi dari pihak ketiga melalui telaah dokumen-dokumen/catatan yang terkait dengan permasalahan yang diteliti.

Analisis dilakukan dengan menggunakan teknik analisis Crosstab yang bertujuan untuk menilai ada atau tidaknya hubungan antara keberadaan wisata bahari dengan pendapatan masyarakat di Desa Kolorai. Adapun uji Crosstab dilakukan dengan menggunakan software SPSS 17. Analisis Crosstab (cross tabulation) adalah alat uji statistik yang digunakan untuk mengidentifikasi korelasi antara dua variabel. Data yang digunakan dalam penelitian ini adalah data berskala nominal dan ordinal. Adapun variabel yang dianalisis terbagi menjadi dua, yaitu variabel bebas dan terikat, yang terjelaskan di Tabel 1 sebagai berikut:

Tabel 1. Variabel Penelitian (Analisis Peneliti, 2020)

\begin{tabular}{|c|c|}
\hline Variabel Bebas & Variabel Terikat \\
\hline $\begin{array}{l}\text { Besar pendapatan sebelum bekerja di sektor wisata } \\
\text { bahari } \\
\text { 1. Rp } 0-500.000,00 \\
\text { 2. Rp } 500.001,00-1.000 .000,00\end{array}$ & $\begin{array}{l}\text { Daya tarik objek wisata } \\
\text { 1. Pantai } \\
\text { 2. Diving } \\
\text { 3. Snorkeling }\end{array}$ \\
\hline $\begin{array}{l}\text { Besar pendapatan setelah bekerja di sektor wisata } \\
\text { bahari } \\
\text { 1. Rp } 1.000 .000,00-1.500 .000,00 \\
\text { 2. Rp } 1.500 .0001,00-2.000 .000,00\end{array}$ & $\begin{array}{l}\text { Kemudahan aksesibilitas } \\
\text { 1. Mudah/terjangkau } \\
\text { 2. Tidak mudah/ kurang terjangkau }\end{array}$ \\
\hline
\end{tabular}

Hipotesis yang digunakan dalam penelitian ini adalah $\mathrm{H}_{0}$ : Tidak ada hubungan antara variabel bebas dan terikat dan $\mathrm{H}_{1}$ : Ada hubungan antara variabel bebas dan terikat. Lebih lanjut, pengambilan keputusan mengenai korelasi antar variabel dilihat berdasarkan probabilitasnya. Dalam uji Crosstab, nilai probabilitas ini dilihat dari Asymptotic Significance (Asymp. Sig). Jika probabilitas lebih besar dari 0,05 maka $\mathrm{H}_{0}$ diterima atau tidak ada hubungan antara dua variabel. Sedangkan apabila probabilitas lebih kecil dari 0,05 maka $\mathrm{H}_{0}$ ditolak atau terdapat hubungan antara dua variabel (Santoso, 2016). 


\section{HASIL DAN PEMBAHASAN}

\subsection{Gambaran pariwisata di Desa Kolorai}

Desa Kolorai memiliki luas wilayah 4,33 $\mathrm{km}^{2}$. Jarak Desa Kolorai dengan Kecamatan Morotai Selatan sekitar $35 \mathrm{~km}^{2}$. Waktu tempuh untuk mencapai Desa Kolorai dari Pelabuhan Daruba, Morotai kurang lebih 1,5 jam dengan menggunakan transportasi speed boat. Namun dengan speed boat berkecepatan yang lebih tinggi waktu tempuh hanya sekitar 20 menit. Desa Kolorai merupakan pusat masyarakat nelayan. Pengunjung dapat bertemu dengan beberapa kampung nelayan di Desa Kolorai. Selain itu, pengunjung juga berkesempatan untuk berkomunikasi dengan nelayan setempat. Nelayan di Desa Kolorai juga sudah beberapa kali mendapatkan pelatihan tentang pengelolaan pariwisata sehingga nelayan di Desa Kolorai sudah cukup terbiasa berinteraksi dengan wisatawan.

Desa Kolorai memiliki daya tarik wisata utama berupa olahraga air, seperti snorkeling dan diving. Keberadaan daya tarik wisata ini juga ditunjang oleh adanya akomodasi pariwisata, seperti sarana transportasi berupa speed boat, perbelanjaan, dan infrastruktur jalan, listrik, dan air bersih yang memadai. Gambar 2 menunjukkan sarana transportasi berupa kapal speed boat yang biasa digunakan untuk alat transportasi sehari-hari masyarakat dan juga wisatawan.

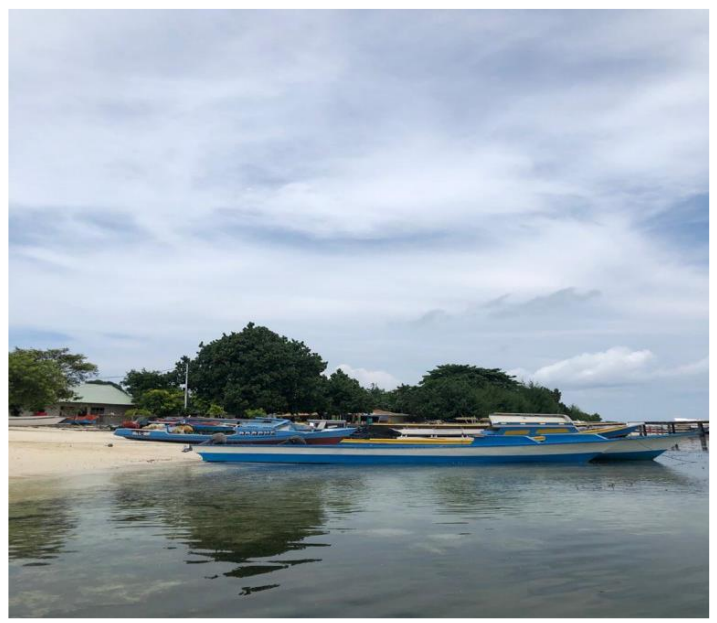

Gambar 2. Sarana Transportasi di Desa Kolorai (Penulis, 2020)

Desa Kolorai juga menjadi pusat wisata di Kecamatan Morotai Selatan. Sebagian besar masyarakatnya bekerja di sektor pariwisata. Hal tersebut dapat berdampak terhadap nilai pendapatan masyarakat dari sebelumnya yang artinya adanya kesempatan berusaha dan lapangan kerja yang berpengaruh terhadap perputaran roda ekonomi masyarakat. Beberapa atraksi lain selain wisata bahari adalah festival Kolorai yang berisikan perlombaan seni dan olahraga. Tujuan festival tersebut adalah untuk mempertahankan warisan budaya setempat. Selain itu, daya tarik wisata lainnya adalah wisatawan dapat terlibat belajar untuk membuat Susiru, Kabilano, dan Tikar Adat. Ada juga kesempatan untuk belajar memasak seafood lokal.

Pengembangan pariwisata yang terjadi menjadikan Desa Kolorai merupakan salah satu wilayah yang masuk dalam Kawasan Strategis Pariwisata Nasional (KSPN) yang ditetapkan pada tahun 2016 karena memiliki potensi wisata yang unggul dari wisata bahari, panorama pantai, dan wisata alam. Desa Kolorai ditetapkan sebagai KSPN karena sesuai untuk kawasan perencanaan karena paling banyak memiliki objek wisata. Jumlah kunjungan wisatawan di Desa Kolorai dari tahun 2015-2019 juga mengalami peningkatan. Hasil telaah dokumen data kunjungan wisatawan dari Dinas Pariwisata Kabupaten Pulau Morotai tahun 2020 menunjukkan bahwa dalam kurun waktu 5 tahun terakhir meningkat tajam dari 3.733 pengunjung di tahun 2015 menjadi 29.101 pengunjung di tahun 2019. Dominasi wisatawan adalah wisatawan domestik.

\subsection{Karakteristik dan upaya pengembangan wisata bahari di Desa Kolorai}

Wisata bahari adalah seluruh kegiatan yang bersifat rekreasi yang aktivitasnya berpusat pada kelautan, seperti daerah pantai, pulau-pulau sekitarnya, serta kawasan lautan. Pulau Kolorai biasa dikenal dengan 
kampung nelayan. Daya tarik wisata bahari yang menjadi unggulan di Desa Kolorai adalah keberadaan pulaupulau kecil dan pantai dengan pasir putih dan air laut yang jernih. Dari beberapa daya tarik wisata pantai tersebut yang menarik minat pengunjung cukup tinggi adalah wisata pantai di Pulau Dodola (Gambar 3).

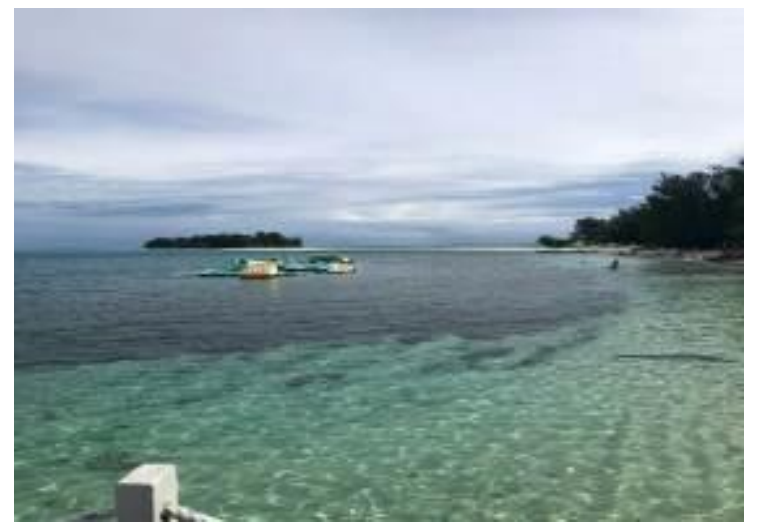

Gambar 3. Wisata Pantai di Pulau Dodola (Penulis, 2020)

Hasil wawancara dengan Kepala Desa Kolorai juga menunjukkan bahwa di Desa Kolorai sudah memiliki kelompok sadar wisata Desa Kolorai yang membantu pemerintah dalam mengelola wisata di Desa kolorai dan juga ikut serta melestarikan wisata bahari yang sudah dikembangkan bersama. Keberadaan wisata bahari tersebut juga membantu bagi perekonomian masyarakat secara ekonomi serta mengubah pola pikir masyarakat menjadi lebih mandiri dan lebih efektif sehingga masyarakat sangat bisa maju secara sosialnya. Lebih lanjut, hasil wawancara dengan kepala Dinas Pariwisata Kabupaten Pulau Morotai juga menyatakan bahwa setiap bulannya pemerintah telah memberikan arahan kepada masyarakat dalam mengelola wisata bahari yang ada. Oleh karena itu, masyarakat setempat diharapkan dapat memanfaatkan berbagai potensipotensi alam. Selain itu, juga adanya program pembinaan seperti program Sadar Wisata (POKDARWIS) yang membantu untuk ikut serta dalam melestarikan wisata bahari. Hal ini menunjukkan bahwa telah ada upaya dari pemerintah setempat untuk mengembangkan wisata bahari di Desa Kolorai.

Beberapa kegiatan-kegiatan wisatawan yang dikembangkan oleh pemerintah adalah seperti kuliner ikan-ikan bakar, ikut berkerajinan daun pandan, pendidikan-pendidikan lingkungan, mengikuti/ terlibat dalam kehidupan nelayan, serta volunteer tourism, dimana peserta wisata tinggal di homestay dan membuat kegiatan-kegiatan sosial untuk membantu masyarakat. Selain itu, juga terkait dengan festival dan upacara adat dari tiga etnis yang terdapat di Desa Kolorai, yaitu suku Galela, suku Tobelo, dan suku Ternate. Pulau Dodola sendiri menjadi fokus utama pengembangan wisata bahari di Desa Kolorai dengan rencana pengembangan seperti di Gambar 4. Program pengembangan wisata bahari di Desa Kolorai berdampak kepada masyarakat dengan memaksimalkan potensi alam, khususnya laut dan pantai yang dimiliki. 


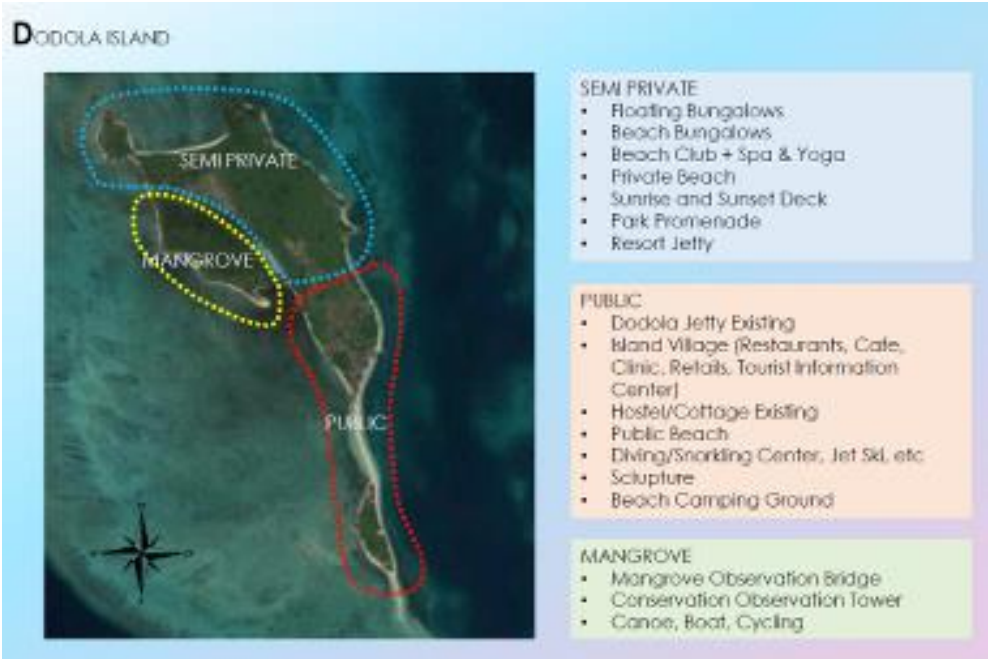

Gambar 4. Masterplan Pengembangan Wisata Kawasan Pulau Dodola (Dinas Pariwisata Kabupaten Pulau Morotai, 2020)

3.3 Analisis dampak pengembangan wisata bahari bagi kondisi ekonomi masyarakat

Analisis dampak pengembangan wisata bahari dilakukan dengan melihat hubungan antara variabel bebas (perubahan pendapatan sebelum dan sesudah bermatapencaharian pada sektor wisata bahari) dan variabel terikat (daya tarik objek wisata bahari dan aksesibilitas) dengan menggunakan Analisis Crosstab.

\subsubsection{Analisis Crosstab variabel aksesibilitas dan pendapatan sebelum bekerja di sektor wisata bahari}

Tabel 2 menunjukkan hasil Crosstab antara variabel aksesibilitas dengan pendapatan sebelum bekerja. Berdasarkan Tabel 2 dapat diketahui dari total 53 responden hasil dari kuesioner terdapat 21 responden yang memilih komponen mudah pada aksesibilitas objek wisata mengatakan transportasi yang digunakan sebelum adanya pengembangan wisata bahari hanya biasa saja dan 32 responden memilih komponen tidak mudah pada aksesibilitas objek wisata. Dari 6 responden yang memilih komponen mudah dengan memiliki pendapatan sebelum bekerja $\mathrm{Rp} 0$ - Rp 500.000,00 terdapat 28 responden yang memiliki pendapatan sebelum bekerja sejumlah Rp 0 - Rp 500.000,00, sebanyak 25 responden dengan pendapatan sebelum bekerja sejumlah $\mathrm{Rp} 500.001,00$ - Rp 1.000.000,00. Tabel 2 juga menunjukkan bahwa ada pengaruh antara variabel pendapatan dengan aksesibilitas. Pendapatan masyarakat dengan aksesibilitas mudah cenderung memiliki jumlah penghasilan yang lebih besar. Namun demikian, jika dilihat dari mayoritas jawaban, sebagian besar responden (60\%) beranggapan bahwa aksesibilitas wisata di Desa Kolorai masih tidak mudah. Hal ini berpengaruh terhadap besaran penghasilan dari sektor wisata bahari.

Tabel 2. Count antara variabel aksesibilitas dan pendapatan sebelum bekerja di sektor wisata bahari (Analisis Peneliti, 2020)

\begin{tabular}{|c|c|c|c|c|}
\hline \multicolumn{5}{|c|}{ Crosstab } \\
\hline \multicolumn{5}{|l|}{ Count } \\
\hline & & \multicolumn{2}{|c|}{ Pendapatan Sebelum bekerja } & \multirow[b]{2}{*}{ Total } \\
\hline & & $\begin{array}{c}\mathrm{Rp} 0-\mathrm{Rp} \\
500.000,00\end{array}$ & $\begin{array}{l}\text { Rp 500.001,00- } \\
\text { Rp 1.000.000,00 }\end{array}$ & \\
\hline \multirow[t]{2}{*}{ Aksesibilitas } & Mudah & 6 & 15 & 21 \\
\hline & Tidak Mudah & 22 & 10 & 32 \\
\hline Total & & 28 & 25 & 53 \\
\hline
\end{tabular}

Tabel 3 menunjukkan hasil analisis Chi-Square Test untuk melihat adanya hubungan antara kedua variabel. Dapat dilihat bagian kolom Asymptotic Significance menunjukkan angka 0,004 $(<0,05)$. Maka $\mathrm{H}_{0}$ ditolak. Artinya ada korelasi antara aksesibilitas dengan pendapatan sebelum bekerja. Berdasarkan tabel 3 
bahwa ada korelasi antara kondisi aksesibilitas dengan pendapatan sebelum bekerja karena memiliki nilai korelasi $<0,05$. Oleh karena itu, bahwa menurunya aksesibilitas dapat menyebabkan pendapatan sebelum bekerja berkurang. Sebanyak $60 \%$ responden berpendapat aksesibilitas di Desa Kolorai belum memadai sehingga penghasilan $60 \%$ responden masih kurang dari Rp 500.000,00. Sementara itu, sebesar $40 \%$ responden lainnya beranggapan aksesibilitas sudah cukup memadai sehingga berpengaruh terhadap besarnya penghasilan.

Tabel 3. Chi-Square Test variabel aksesibilitas dan pendapatan sebelum bekerja di sektor wisata bahari (Analisis Peneliti, 2020)

\begin{tabular}{|l|r|r|r|r|r|}
\hline \multicolumn{7}{|c|}{ Chi-Square Tests } \\
\hline & Value & df & $\begin{array}{c}\text { Asymptotic } \\
\text { Significance (2-sided) }\end{array}$ & $\begin{array}{c}\text { Exact Sig. } \\
\text { (2-sided) }\end{array}$ & $\begin{array}{c}\text { Exact Sig. (1- } \\
\text { sided) }\end{array}$ \\
\hline Pearson Chi-Square & $8.214^{\mathrm{a}}$ & 1 & .004 & & \\
\hline Continuity Correction & 6.680 & 1 & .010 & & \\
\hline Likelihood Ratio $^{\mathrm{b}}$ & 8.427 & 1 & .004 & & .006 \\
\hline Fisher's Exact Test & & & & .005 & \\
\hline Linear-by-Linear Association & 8.059 & 1 & & & \\
\hline N of Valid Cases & 53 & & & & \\
\hline a. 0 cells (,0\%) have expected Count less than 5. The minimum expected Count is 9,91. \\
\hline b. Computed only for a 2x2 table \\
\hline
\end{tabular}

\subsubsection{Analisis Crosstab variabel aksesibilitas dan pendapatan setelah bekerja di sektor wisata bahari}

Tabel 4 memperlihatkan korelasi variabel aksesibilitas dengan pendapatan setelah bekerja di sektor wisata bahari. Berdasarkan Tabel 4 dapat diketahui dari total 53 responden terdapat 37 responden yang memilih komponen mudah pada aksesibilitas karena dari hasil wawancara mereka bisa mendapatkan pekerjaan baru yang artinya meningkatkan kondisi perekonomian. Sedangkan 16 responden berpendapat bahwa aksesibilitas objek wisata tidak mudah. Dari 37 responden yang memilih komponen mudah pada aksesibilitas objek wisata, terdapat 31 responden yang memiliki pendapatan sesudah bekerja sejumlah $\mathrm{Rp}$ 1.000.000,00 - Rp 1.500.000,00, dan 6 responden dengan pendapatan sesudah bekerja sejumlah Rp $1.500 .001,00-R p 2.000 .000,00$. Sedangkan pada 16 responden yang beranggapan bahwa aksesibilitas objek wisata tidak mudah terdapat 8 responden yang memiliki pendapatan sesudah bekerja sejumlah $\mathrm{Rp}$ $1.000 .000,00-R p 1.500 .000,00$, dan 8 responden dengan pendapatan sebelum bekerja sejumlah $\mathrm{Rp}$ $1.500 .001,00$ - Rp 2.000.000,00. Tabel 4 menunjukkan bahwa keberadaan wisata bahari telah membuat aksesibilitas menjadi lebih berkembang/ mudah. Hal ini dinyatakan oleh $70 \%$ responden. Sebagai dampaknya, terdapat kenaikan pendapatan masyarakat di sektor wisata menjadi antara Rp 1.500.001,00 hingga Rp 2.000.000,00 dari sebelumnya hanya berada pada kisaran Rp 500.000,00 hingga Rp 1.000.000,00.

Tabel 4. Count antara variabel aksesibilitas dan pendapatan sesudah bekerja di sektor wisata bahari (Analisis Peneliti, 2020)

\begin{tabular}{|l|l|r|r|r|}
\hline \multicolumn{9}{|c|}{ Crosstab } \\
\hline \multicolumn{4}{|c|}{ Count } & \multicolumn{2}{c|}{ Pendapatan sesudah bekerja } & \\
\cline { 3 - 6 } & Rp 1.000.000,00 - & Rp 1.500.001,00- & \\
& Rp 1.500.000,00 & Rp 2.000.000,00 & Total \\
\hline Aksesibilitas & Mudah & 8 & 31 & 37 \\
\cline { 2 - 6 } & Tidak Mudah & 14 & 8 & 16 \\
\hline Total & & & 39 & 53 \\
\hline
\end{tabular}

Tabel 5 menunjukkan hasil analisis Chi-Square Test untuk melihat adanya hubungan antara kedua variabel. Pada Tabel 5 hasil analisis chi-square test memperlihatkan pada bagian kolom Asymptotic 
Significance menunjukkan angka $0,010(<0,05)$, maka $\mathrm{H}_{0}$ ditolak. Artinya ada hubungan antara aksesibilitas objek wisata dengan pendapatan sesudah bekerja di sektor wisata.

Tabel 5. Chi Square Test variabel aksesibilitas dan pendapatan sesudah bekerja di sektor wisata bahari

(Analisis Peneliti, 2020)

\begin{tabular}{|l|r|r|r|r|r|}
\hline & Value & df & $\begin{array}{c}\text { Asymptotic } \\
\text { Significance } \\
\text { (2-sided) }\end{array}$ & $\begin{array}{l}\text { Exact Sig. } \\
\text { (2-sided) }\end{array}$ & $\begin{array}{c}\text { Exact Sig. (1- } \\
\text { sided) }\end{array}$ \\
\hline Pearson Chi-Square & $6.559^{\mathrm{a}}$ & 1 & .010 & & \\
\hline Continuity Correction ${ }^{\text {b }}$ & 4.936 & 1 & .026 & & \\
\hline Likelihood Ratio $^{2}$ & 6.219 & 1 & .013 & & \\
\hline Fisher's Exact Test & & & & .011 & \\
\hline $\begin{array}{l}\text { Linear-by-Linear } \\
\text { Association }\end{array}$ & 6.435 & 1 & & & \\
\hline N of Valid Cases & 53 & & & & \\
\hline a. O cells (,0\%) have expected Count less than 5. The minimum expected Count is 6,34. \\
\hline b. Computed only for a 2x2 table \\
\hline
\end{tabular}

\subsubsection{Analisis Crosstab variabel daya tarik wisata dan pendapatan sebelum bekerja di sektor wisata bahari}

Tabel 6 menunjukkan korelasi antara daya tarik wisata dengan pendapatan sebelum bekerja di sektor wisata bahari. Berdasarkan Tabel 6 dapat diketahui dari total 53 responden terdapat 17 responden yang memilih komponen pantai pada daya tarik objek wisata dan 17 responden memilih komponen diving pada daya tarik wisata sedangkan 19 responden memilih komponen Snorkeling. Dari 17 responden yang memilih komponen pantai pada daya tarik objek wisata, terdapat 3 responden yang memiliki pendapatan sebelum bekerja sejumlah $\mathrm{Rp} 0$ - Rp 500.000,00, sebesar 14 responden dengan pendapatan sebelum bekerja sejumlah Rp 500.001,00 - Rp 1.000.000,00, sebanyak 17 responden yang memilih komponen diving pada daya tarik objek wisata, terdapat 6 responden yang memiliki pendapatan sebelum bekerja sejumlah Rp $0-\mathrm{Rp}$ $500.000,00$, sejumlah 11 responden dengan pendapatan sebelum bekerja sejumlah Rp 500.001,00 - Rp $1.000 .000,00$. Sedangkan 19 responden yang memilih komponen Snorkeling pada daya tarik wisata terdapat terdapat 11 responden yang memiliki pendapatan sebelum bekerja sejumlah $R p 0-R p 500.000,00$, sebanyak 8 responden dengan pendapatan sebelum bekerja sejumlah Rp 500.001,00 - Rp 1.000.000,00. Tabel 6 juga memperlihatkan bahwa keberadaan daya tarik atau atraksi wisata mempengaruhi tingkat pendapatan sebelum bekerja di dalamnya. Sebanyak $62 \%$ responden berpendapat bahwa daya tarik wisata yang terdiri dari wisata pantai, diving, dan snorkeling mempengaruhi besaran pendapatan. Sementara itu, keberadaan wisata pantai yang paling mempengaruhi tingkat pendapatan.

Tabel 6. Count antara variabel daya tarik wisata dan pendapatan sebelum bekerja di sektor wisata bahari

(Analisis Peneliti, 2020)

\begin{tabular}{|c|c|c|c|c|}
\hline \multicolumn{5}{|c|}{ Crosstab } \\
\hline \multicolumn{5}{|l|}{ Count } \\
\hline & & \multicolumn{2}{|c|}{ Pendapatan Sebelum bekerja } & \multirow[b]{2}{*}{ Total } \\
\hline & & $\begin{array}{c}\mathrm{Rp} 0-\mathrm{Rp} \\
500.000,00\end{array}$ & $\begin{array}{l}\text { Rp 500.001,00- } \\
\text { Rp 1.000.000,00 }\end{array}$ & \\
\hline \multirow[t]{3}{*}{ Daya tarik wisata } & Pantai & 3 & 14 & 17 \\
\hline & Diving & 6 & 11 & 17 \\
\hline & Snorkeling & 11 & 8 & 19 \\
\hline \multicolumn{2}{|l|}{ Total } & 20 & 33 & 53 \\
\hline
\end{tabular}


Tabel 7 menunjukkan analisis Chi Square Test yang dapat dilihat bagian kolom Asymptotic Significance menunjukkan angka $0,044(<0,05)$, maka $\mathrm{H}_{0}$ ditolak. Artinya ada hubungan antara daya tarik wisata dengan pendapatan sebelum bekerja. Oleh karena itu, daya tarik wisata berpengaruh dengan pendapatan sebelum bekerja di sektor wisata bahari.

Tabel 7. Chi Square Test variabel daya tarik wisata dan pendapatan sebelum bekerja di sektor wisata bahari (Analisis Peneliti, 2020)

\begin{tabular}{|l|l|l|l|}
\hline \multicolumn{4}{|c|}{ Chi-Square Tests } \\
\hline & \multicolumn{1}{|c|}{ Value } & df & $\begin{array}{c}\text { Asymptotic } \\
\text { Significance } \\
\text { (2-sided) }\end{array}$ \\
\hline Pearson Chi-Square & $6.249^{\mathrm{a}}$ & 2 & .044 \\
\hline Likelihood Ratio & 6.470 & 2 & .039 \\
\hline Linear-by-Linear Association & 6.102 & 1 & .014 \\
\hline N of Valid Cases & 53 & \multicolumn{3}{|l|}{} \\
\hline $\begin{array}{l}\text { a. } 2 \text { cells (33,3\%) have expected Count less than 5. The minimum expected Count } \\
\text { is }, 40 .\end{array}$
\end{tabular}

3.3.4 Analisis Crosstab variabel daya tarik wisata dan pendapatan sesudah bekerja di sektor wisata bahari

Berdasarkan Tabel 8 dapat diketahui dari total 53 responden terdapat 13 responden yang memilih komponen pantai pada daya tarik objek wisata dan 19 responden memilih komponen diving pada daya tarik wisata, sedangkan 21 responden memilih komponen snorkeling sebagai daya tarik wisata. Dari 28 responden yang memilih komponen pantai pada daya tarik objek wisata, terdapat 7 responden yang memiliki pendapatan sesudah bekerja sejumlah $\mathrm{Rp} 1.000 .000,00$ - Rp 1.500.000,00, dan sebesar 6 responden dengan pendapatan sesudah bekerja sejumlah $\mathrm{Rp} 1.500 .001,00-\mathrm{Rp} 2.000 .000,00$. Dari 19 responden yang memilih komponen diving pada daya tarik objek wisata, terdapat 13 responden yang memiliki pendapatan sesudah bekerja sejumlah Rp 1.000.000,00 - Rp 1.500.000,00, dan sebanyak 6 responden dengan pendapatan sesudah bekerja sejumlah Rp 1.500.001,00 - Rp 2.000.000,00. Sedangkan pada 21 responden yang memilih Snorkeling pada daya tarik wisata terdapat 6 responden yang memiliki pendapatan sesudah bekerja sejumlah Rp 1.000.000,00 - Rp 1.500.000,00, dan sebanyak 15 responden dengan pendapatan sebelum bekerja sejumlah Rp 1.500.001,00 - Rp 2.000.000,00

Tabel 8 menunjukkan count bahwa sebesar $53 \%$ responden merasakan ada kenaikan pendapatan dengan adanya daya tarik wisata bahari, dari sebelumnya hanya berkisar antara Rp 500.000,00 hingga Rp $1.000 .000,00$ menjadi Rp 1.500.001,00 hingga Rp 2.500.000,00. Jenis atraksi wisata snorkeling yang paling berkontribusi bagi kenaikan pendapatan, dimana sebesar $40 \%$ responden merasakan dampak snorkeling ini. Keindahan wisata pantai di Pulau Kolorasi dan Dodola mempengaruhi besarnya minat wisatawan untuk melakukan Snorkeling.

Tabel 8. Count antara variabel daya tarik wisata dan pendapatan sesudah bekerja di sektor wisata bahari (Analisis Peneliti, 2020)

\begin{tabular}{|l|l|r|r|r|}
\hline \multicolumn{9}{|c|}{ Crosstab } \\
\hline \multicolumn{4}{|c|}{ Count } & \multicolumn{2}{|c|}{ Pendapatan sesudah bekerja } & \\
\cline { 3 - 6 } & $\begin{array}{r}\text { Rp 1.000.000,00 - } \\
\text { Rp 1.500.000,00 }\end{array}$ & $\begin{array}{r}\text { Rp 1.500.001,00- } \\
\text { Rp 2.000.000,00 }\end{array}$ & \\
Total \\
\hline \multirow{2}{*}{ Daya tarik wisata } & Pantai & 6 & 7 & 13 \\
\cline { 2 - 6 } & Diving & 13 & 6 & 19 \\
\cline { 2 - 6 } & Snorkeling & 6 & 15 & 21 \\
\hline Total & 25 & 28 & 53 \\
\hline
\end{tabular}


Tabel 9 menunjukkan hasil analisis chi-square test digunakan untuk mendapatkan adanya hubungan atau pengaruh dua buah variabel nominal (uji independent antara dua variabel). Dapat dilihat pada bagian kolom Asymptotic Significance menunjukkan angka 0,042 $(<0,05)$, maka $\mathrm{H}_{0}$ ditolak. Artinya ada hubungan antara aksesibilitas objek wisata dengan pendapatan sesudah bekerja. Responden mengaggap bahwa daya tarik wisata menjadikan penghasilan meningkat karena sudah mendapatkan pekerjaan baru dari hasil pengembangan wisata.

Tabel 9. Chi Square Test variabel daya tarik wisata dan pendapatan sesudah bekerja di sektor wisata bahari (Analisis Peneliti, 2020)

\begin{tabular}{|c|c|c|c|c|c|}
\hline \multicolumn{6}{|c|}{ Chi-Square Tests } \\
\hline & Value & df & $\begin{array}{c}\text { Asymptotic } \\
\text { Significance (2- } \\
\text { sided) }\end{array}$ & $\begin{array}{l}\text { Exact Sig. (2- } \\
\text { sided) }\end{array}$ & $\begin{array}{l}\text { Exact Sig. (1- } \\
\text { sided) }\end{array}$ \\
\hline Pearson Chi-Square & $6.364^{\mathrm{a}}$ & 2 & .042 & & \\
\hline Continuity Correction ${ }^{b}$ & 6.533 & 2 & .038 & & \\
\hline Likelihood Ratio & 1.710 & 1 & .191 & & \\
\hline Fisher's Exact Test & 53 & & & .573 & .288 \\
\hline $\begin{array}{l}\text { Linear-by-Linear } \\
\text { Association }\end{array}$ & .694 & 1 & .405 & & \\
\hline $\mathrm{N}$ of Valid Cases & 53 & & & & \\
\hline \multicolumn{6}{|c|}{ a. 0 cells $(, 0 \%)$ have expected Count less than 5 . The minimum expected Count is 9,51 . } \\
\hline ly for a & ble & & & & \\
\hline
\end{tabular}

Dari hasil analisis Crosstab yang telah dilakukan dapat disimpulkan aksesibilitas berhubungan dengan kondisi peningkatan pendapatan masyarakat di Desa Kolorai mencapai 60\% - 80\% dan 80\% - 100\% dengan pendapatan masyarakat Rp 1.500.001,00 hingga Rp 2.000.000,00 per bulan. Hal ini karena aksesibilitas dapat memprediksikan kondisi peningkatan pendapatan masyarakat. Oleh karena itu, aksesibilitas merupakan salah satu hal yang penting dalam menunjang kelancaran berwisata. Akses jalan yang baik di kawasan wisata merupakan salah satu faktor penting penunjang kepuasan dan kenyamanan wisatawan karena membuat kegiatan wisata yang dilakukan menjadi lancar.

Sementara itu, dari analisis variabel daya tarik wisata, daya tarik wisata yang memberi kontribusi terbesar bagi wisata bahari di Desa Kolorai adalah snorkeling yang berpengaruh pada kenaikan pendapatan masyarakat sebesar Rp 1.500.001,00 hingga Rp 2.000.000,00 per bulan. Daya tarik wisata merupakan faktor bagi wisatawan dalam mempengaruhi pengambilan keputusan mengunjungi destinasi wisata. Hal ini didukung dengan terbukanya lapangan pekerjaan yang juga dampak dari pengembangan wisata bahari yang dimana peluang bisnis dilakukan di dalam Kawasan objek wisata. Oleh karena itu, masyarakat memiliki sumber pendapatan yang memadai. Hal ini sejalan dengan dengan berbagai aktivitas di dalam kawasan wisata bahari yang memberikan nilai tambah. Daya tarik wisata menjadi salah satu usaha untuk menarik wisatawan untuk berkunjung.

\section{KESIMPULAN}

Keberadaan wisata bahari di Desa Kolorai memberi dampak yang cukup signifikan bagi perekonomian masyarakat lokal. Hal ini dapat dilihat dari adanya kesempatan lapangan pekerjaan yang terbuka dengan adanya atraksi pariwisata. Perubahan mata pencaharian merupakan pengaruh yang dirasakan secara langsung oleh masyarakat dalam jangka waktu pendek. Masyarakat yang sebelumnya hanya bermatapencaharian sebagai nelayan, mendapatkan peluang pekerjaan baru dengan kegiatan pariwisata. Kondisi ini juga didukung oleh peran pemerintah dalam memberikan pemahaman mengenai kepariwisataan bagi masyarakat lokal. Sebagai dampaknya, masyarakat tidak hanya mengandalkan satu profesi sebagai sumber penghasilannya, tetapi juga mampu melakukan kegiatan ekonomi lainnya melalui usaha-usaha yang 
berkaitan dengan wisata, seperti jasa akomodasi. Temuan ini mengkonfirmasi penelitian sebelumnya bahwa keberadaan sektor pariwisata berperan bagi peningkatan ekonomi dan kesejahteraan masyarakat (Hiariey \& Sahusialawane, 2013; Rahman \& Muktialie, 2014; Shantika \& Mahagangga, 2018). Kunjungan wisatawan dimanfaatkan sebagai peluang oleh masyarakat lokal untuk meningkatkan pendapatan, baik melalui penawaran jasa, tenaga ataupun keahlian yang mereka punya berhubungan dengan kegiatan wisata bahari.

\section{DAFTAR PUSTAKA}

Astuti, M. T., \& Noor, A. A. (2016). Daya Tarik Morotai Sebagai Destinasi Wisata Sejarah dan Bahari. Jurnal Kepariwisataan Indonesia, 11(1), 25-46.

Dritasto, A., \& Anggraeni, A. A. (2013). Analisis Dampak Ekonomi Wisata Bahari Terhadap Pendapatan Masyarakat di Pulau Tidung. Reka Loka, Januari, 1-8.

Fyka, S., Yunus, L., Limi, M., Hamzah, A., \& Darwan, D. (2018). Analisis Dampak Pengembangan Wisata Pulau Bokori Terhadap Kondisi Sosial Ekonomi Masyarakat Bajo (Studi Kasus di Desa Mekar Kecamatan Soropia). Habitat, 29(3), 106-112. https://doi.org/10.21776/ub.habitat.2018.029.3.13

Hiariey, L. S., \& Sahusialawane, W. (2013). Dampak Parisata Terhadap Pendapatan dan Tingkat Kesejahteraan Pelaku Usaha di Kawasan Wisata Pantai Natsepa, Pulau Ambon. Jurnal Organisasi Dan Manajemen, 9(1), 87-105.

Koroy, K., Nurafni, N., \& Mustafa, M. (2018). Analisis Kesesuaian dan Daya Dukung Ekosistem Terumbu Karang sebagai Ekowisata Bahari di Pulau Dodola Kabupaten Pulau Morotai. Jurnal Enggano, 3(1), 52 64.

Muawanah, U., Triyanti, R., \& Soejarwo, P. A. (2020). Dampak Ekonomi Wisata Bahari di Kabupaten Alor. Jurnal Sosial Ekonomi Kelautan Dan Perikanan, 15(1), 33-46. https://doi.org/10.15578/jsekp.v1i1.8841

Muljadi, M., \& Warman, A. (2014). Kepariwisataan dan Perjalanan. Raja Grafindo Persada.

Nastiti, C. E. P., \& Umilia, E. (2013). Faktor Pengembangan Kawasan Wisata Bahari di Kabupaten Jember. Jurnal Teknik POMITS, 2(2), 164-167.

Natan, N. (2016). Prospek Pariwisata Morotai. Jurnal Media Wisata, 14(1), 305-316.

Rahman, Y., \& Muktialie, M. (2014). Pengaruh Aktivitas Pariwisata Pantai Taplau Kota Padang Terhadap Ekonomi, Sosial Masyarakat, dan Lingkungan. Jurnal Teknik PWK, 3(4), 979-990.

Razak, F. ., Suzana, B. O. L., \& Kapantow, G. H. M. (2017). Strategi Pengembangan Wisata Bahari Pantai Malalayang, Kota Manado, Sulawesi Utara. Agri-Sosioekonomi, 13(1A), 277-284. https://doi.org/10.35791/agrsosek.13.1a.2017.16180

Santoso, S. (2016). Panduan Lengkap SPSS Versi 23. PT Elex Media Komputindo.

Shantika, B., \& Mahagangga, I. G. A. O. (2018). Dampak Perkembangan Pariwisata Terhadap Kondisi Sosial Ekonomi Masyarakat di Pulau Nusa Lembongan. Jurnal Destinasi Pariwisata, 6(1), 177-183. https://doi.org/10.24843/jdepar.2018.v06.i01.p27

Undang-Undang No.10 Tahun 2009 tentang Kepariwisataan. 